\title{
Evaluation on mechanical properties of woven aloevera and sisal fibre hybrid reinforced epoxy composites
}

\author{
A SHADRACH JEYA SEKARAN ${ }^{1,2}, K_{\text {PALANI KUMAR }}^{3, *}$ and K PITCHANDI ${ }^{4}$ \\ ${ }^{1}$ Anna University, Chennai 600 025, India \\ ${ }^{2}$ Department of Mechanical Engineering, St. Peter's College of Engineering and Technology, \\ Chennai 600 054, India \\ ${ }^{3}$ Department of Mechanical Engineering, Sri Sai Ram Institute of Technology, West Tambaram, Chennai 600 044, India \\ ${ }^{4}$ Department of Mechanical Engineering, Sri Venkateswara College of Engineering, Sriperumbudur, \\ Chennai 602 107, India
}

MS received 15 April 2015; accepted 13 May 2015

\begin{abstract}
Natural fibres as reinforcement in polymer composite for making low-cost materials are growing day by day. Researcher's main attention is to apply appropriate technology to utilize these natural fibres as effectively and economically as possible to produce good quality fibre-reinforced polymer composites for various engineering applications. In this research, the experiments of tensile, flexural and impact tests were carried out for woven aloevera and sisal fibre hybrid-reinforced epoxy composites. The hand layup method of fabrication was employed in preparing the composites. The surface morphology of the composites was examined through scanning electron microscope. Due to the low-density and high-specific properties of sisal fibre composites, it offer cost savings when compared with synthetic fibres. Hence it has very good implications in the automotive and transportation industry.
\end{abstract}

Keywords. Woven aloevera; sisal; epoxy composites; tensile test; flexural test; impact test.

\section{Introduction}

Natural fibres are emerging as low cost, light weight and apparently environmentally superior alternatives to glass fibres in composites. Reasons to go for natural fibre composites is natural fibre production has lower environmental impacts compared to glass fibre production. Because of its light weight, natural fibre composites improve fuel efficiency and reduce emissions, especially in auto applications. ${ }^{1}$ Sisal and aloevera fibre along with some other natural fibre extraction process have been reviewed with the polymers used in creating composites along with the suitable manufacturing process employed and its mechanical properties are compared. ${ }^{2}$ However, there is still uncertainity on which type of manufacturing processes is suitable for producing these natural composites. For small to medium sized components, injection and compression mouldings are preferred due to their simplicity and fast processing cycle. However, for large structures, they are typically manufactured by open moulding and autoclave processes. Similar to other plastic products, the complexity of shape of a product also influences the type of manufacturing processes to be used. For

\footnotetext{
*Author for correspondence (palanikumar_k@yahoo.com)
}

example, filament winding is the most suitable method for manufacturing composite's pressure vessels and cylinders. Pultrusion is mainly used for producing long and uniform cross-section parts. To some extent, optic fibre can be integrated into the pultrusion process to produce self-structural-health monitored composite structures. ${ }^{3}$ The cellulosic content of the fibres which varies from fibre to fibre, influences the mechanical properties of composites mainly by the adhesion between matrix and fibres. Chemical and physical modification methods were incorporated to improve the fibre-matrix adhesion resulting in the enhancement of mechanical properties of the composites. ${ }^{4}$ Particle size, short fibre and long fibre randomly oriented intimately mixed Hibiscus sabadariffa natural fibre reinforced with urea formaldehyde resin composite is tested for its tensile and compressive strength for its various fibre loadings and the mechanical behaviour of this composite is observed to be more effective. ${ }^{5}$ The fibre length plays a prominent role in deciding the mechanical properties of sisal composite compared with fibre content when experimented by untreated short sisal fibre-reinforced vinyl ester polymer-based composites for various fibre lengths of 10,30 and $50 \mathrm{~mm} .^{6}$ Chemical and physical treatments of sisal fibre increases fibre strength and the adhesion between the fibre bundles and the matrix resulting in the improvement of mechanical properties, especially tensile properties of sisal laminates. 
Fibre-surface treatment can improve the adhesion properties between sisal fibre and matrix and simultaneously reduce water absorption. Different matrix systems have different properties. The mechanical and physical properties of sisal fibre-reinforced composites are very sensitive to processing methods, fibre length, fibre orientation and fibre-volume fraction. ${ }^{8}$ Compared to untreated and $\mathrm{NaOH}$-treated sisal fibres, the best performance sisal/ polyester composites are likely to be produced when sisal fibres are treated with $2.0 \% \mathrm{~N}$-isopropyl acrylamide aqueous solution. Not only does the reinforcement present higher tensile strength and lower moisture absorption, but also best results in pull-out tests with polyester matrix. ${ }^{9}$ The alkali treatment found to be effective in improving the tensile and flexural properties, while the impact strength decreased for Roystonea regia (royal palm) natural-fibre-reinforced epoxy composites. ${ }^{10}$ Flax fibrereinforced polymeric composites show improvement in the interface between fibres and matrix when flax fibres undergo chemical treatments, such as mercerization, silane treatment and benzoylation, etc. Also, the use of nanotechnology (flax nanofibres and the addition of nanoclays in flax composites) highly improves the mechanical performances. ${ }^{11}$ Rule of hybrid mixture ( RoHM) is used to predict the tensile properties of short random oriented hybrid composites of sisal and banana. Experimental values are found to be little lower than numerical investigated values. This may be due to the chance of formation of microvoids between fibre and matrix during the preparation of composites and it greatly influences the tensile properties. ${ }^{12}$ The tensile fatigue behaviour of long aligned sisal fibre-reinforced cement composites was examined in terms of the stress $v s$. cycles and stress-strain hysteresis behaviour of the composites. Composites were tested at stress levels ranging between 4 and $9.8 \mathrm{MPa}$, which represent approximately $30-80 \%$ of the monotonic ultimate tensile strength. The composites did not fail in fatigue below a maximum fatigue level of $6 \mathrm{MPa}$ up to 106 cycles. There was no observed loss in strength, but a decrease in Young's modulus and an increase in first crack strength were observed with the increase in fatigue stress. ${ }^{13}$ Tensile strength of hemp shive composite is increased up to $40 \%$ of its content, after that decrement takes place due to the formation of particles agglomerations after the filler exceeds the optimal filler content value. ${ }^{14}$ Sisal with glass fibre-reinforced plastic (GFRP) and jute with GFRP hybrid composite specimens are prepared and subjected to tensile and flexural loading. The sisal/GFRP composite samples possess good tensile strength and can withstand the strength up to $68.55 \mathrm{MPa}$. The jute/GFRP composite specimen is holding the maximum flexural load of $1.03 \mathrm{kN}$, slightly higher than the sisal/GFRP composite sample. ${ }^{15}$ The mechanical properties of sisal-pineapple leaf fibre (PALF)-banana-glass fibre reinforced with polyester hybrid composites were investigated. From the observation it is found out that there is a vast increase in the tensile strength, flexural strength and impact strength of sisal-PALF-banana fibre when it is reinforced with glass fibre in the polyester matrix composites. ${ }^{16}$ Tensile, flexural and impact strength of woven banana and glass fibre epoxy composites is determined and flexural property is found to be good and similar displacement is observed for both the composites. ${ }^{17}$ The mechanical properties of the hybrid composites were found to be enhanced linearly with the volume fraction of high strength fibres up to certain maximum value beyond which a negative hybrid effect had been observed because of formation of agglomerates. ${ }^{18}$ Natural fibrereinforced biodegradable polymer composites are the materials that have the capability to fully degrade and compatible with the environment. ${ }^{19}$ Industrial waste, mainly seeds and fibres, of acar fruit and these fibres are used to obtain composites with natural rubber from different clones and it is investigated for its mechanical and thermal properties comparable to those with other natural fibres industrially used in polymeric composites. ${ }^{20} \mathrm{~A}$ green composite oil palm trunk lumber is made by reinforcing oil palm shell with formaldehyde resin. The changes in mechanical properties were observed by keeping in natural weathering for the period of 6-12 months. This investigation makes the way for improved natural composites in outdoor conditions. ${ }^{21}$ Tensile strength, flexural stress, flexural strain and tangent modulus of the bamboo fibre and polyvinyl chloride (PVC) foam sheet composites are observed to increase, while the tensile strain decreases with the subsequent addition of the fibre to the PVC sheets. ${ }^{22}$ In this research work an attempt has been made to study the mechanical properties of woven aloevera and sisal fibre hybrid-reinforced epoxy composites with SEM analysis.

\section{Experimental}

\subsection{Materials}

The natural fibres extracted from aloevera and sisal plant in woven form, which is presented in figure 1, were procured from Anakaputhur Jute Weaver Association, Chennai, India. Matrix material selected for making composite was epoxy resin grade B-11 (3101) and hardener grade K-6 (5205) as binder for the resin. Composite fabrication and testing specimen's preparation was carried out at Creative Composites, Chennai, India. Mechanical testing was carried out at METMECH Engineers (Research Lab), Chennai, India.

\subsection{Composite preparation}

The hybrid composite laminates were prepared by the hand layup process. Woven aloevera and sisal fibres were reinforced separately by alternative layers into epoxy 

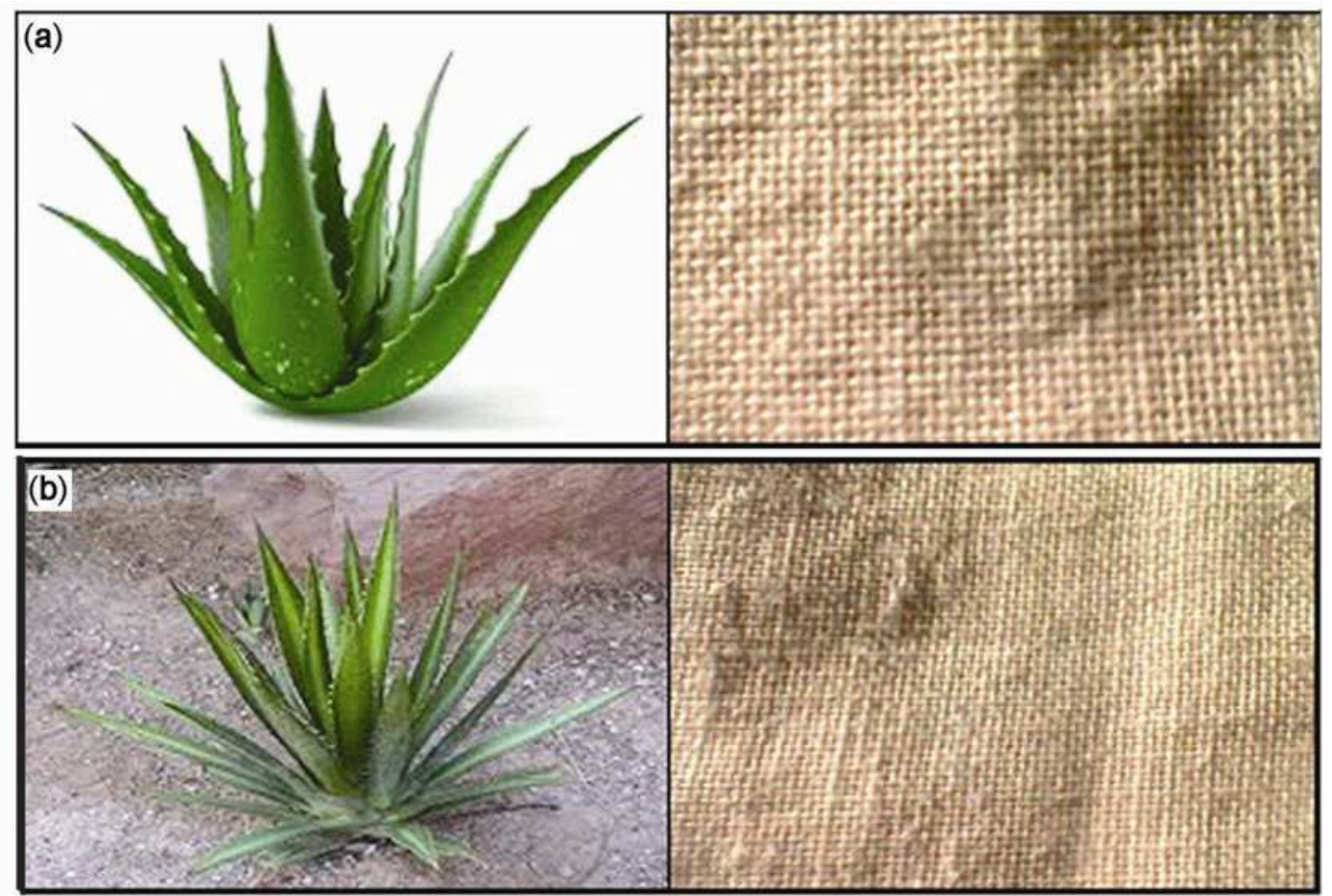

Figure 1. Woven natural fibres from aloevera and sisal.

resin grade B-11 (3101) and the hardener grade K-6 (5205) was mixed in a ratio of $10: 1$. Proper stirring was carried out during the mixing of resin and hardener. Careful attention was taken to disperse the resin and the hardener into the matrix. The woven aloevera fibre mat measures $300 \times 300 \mathrm{~mm}$ as the first layer was kept on the epoxy resin film coating. Then resin film coating was carried out with uniformity on the entire surface of the fibre mat. After that second layer of woven sisal fibre mat was kept for the same dimensions and the epoxy resin was applied and fills over the entire surface of the fibre mat. In similar way the alternate woven aloevera and sisal fibre mats were placed in between each resin coatings. The process was repeated until a thickness of $3.2 \mathrm{~mm}$ was obtained in the laminates. The air gaps formed between the layers during fabrication were removed out by using the rollers. Then the laminated was compressed for a curing time of $24 \mathrm{~h}$. The prepared hybrid composite laminate of woven aloevera and sisal is presented in figure 2. Similarly, aloevera and sisal laminates were prepared with the same fibre mat itself.

\subsection{Specimen preparation}

After the curing process, from the woven aloevera and sisal hybrid composite laminate, specimens for tensile, flexural and impact tests were prepared using saw cutter. The edges of the specimen were smoothened by using file and emery sheet. The specimens were cut to the required size prescribed as per ASTM standards ${ }^{23-28}$ and the

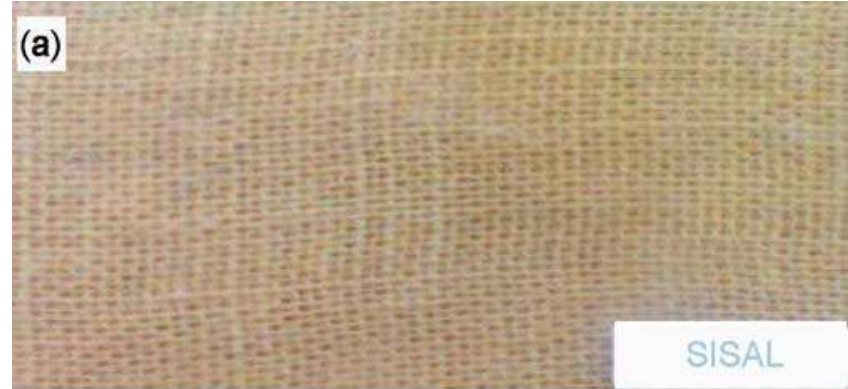

(b)

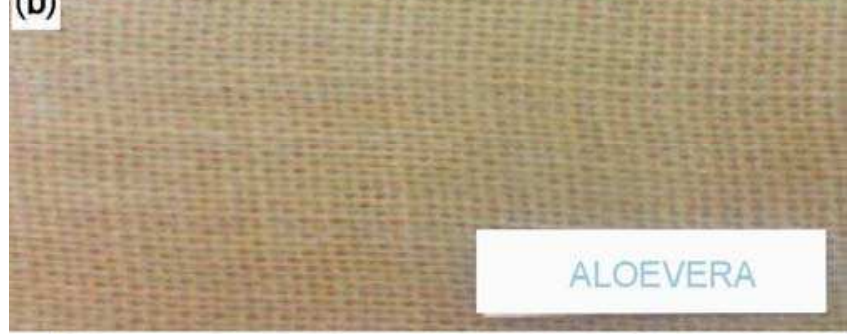

(c)

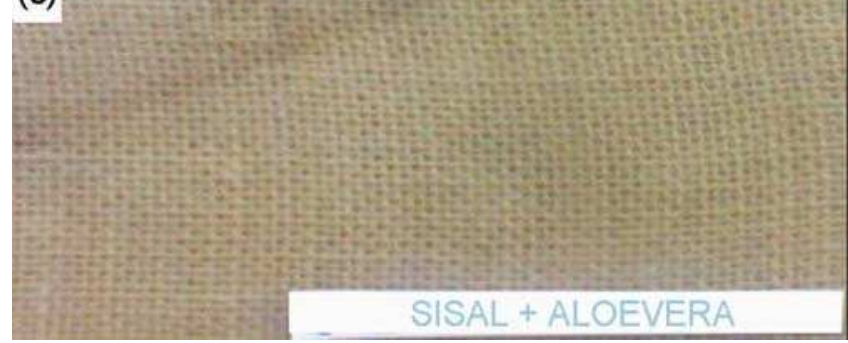

Figure 2. (a) Woven sisal, (b) aloevera and (c) sisal and aloevera hybrid composite laminate. 
specimens before testing and after testing are presented in figures 3-5.

\subsection{Mechanical properties}

2.4a Tensile testing: In universal testing machine (UTM) the tensile test was carried out at a speed of $2.5 \mathrm{~mm} \mathrm{~min}^{-1}$. The standard followed for tensile testing was ASTM D638. Three samples were tested from woven aloevera, sisal and its hybrid composites. The samples were prepared in the dog bone shape or dumb bell shape according to the standards mentioned above. In each case, the specimens were tested to obtain the average value. The tensile test was carried out by clamping the specimen in the required fixture of the machine and load was applied until the specimen breaks. The stress-strain and load-displacement graphs generated from the machine for the woven composites during the test are presented in figures 6 and 7, respectively.

2.4b Flexural testing: The flexural test (three-point bending) was carried out using UTM according to ASTM standard D790. Three samples were prepared as per the above standard from woven aloevera, sisal and its hybrid composite. The deflection of the specimen was measured under a compressive load until the specimen breaks or cracks. In each case, the specimens were tested to obtain the average value. The stress-strain graph generated from the machine for the hybrid woven composites during the test are presented in figures 8 and 9. During the experiment the top surface layer of the specimen was subjected to compression and the bottom surface layer of the same specimen was subjected to tension. The middle layer was subjected to shear. Thus, flexural behaviour was analysed until the failure of the composite specimen takes place due to the combination of bending and shear.

2.4c Impact testing: The impact strength of the composite specimens were determined by using an Izod impact tester. It is the measure of resistance offered by the composite specimen against fracture by applying heavy impact load. The specimens were prepared from woven aloevera, sisal and its hybrid composites according to the ASTM D256 standard. In each case, minimum of three specimens were tested to obtain the average value.
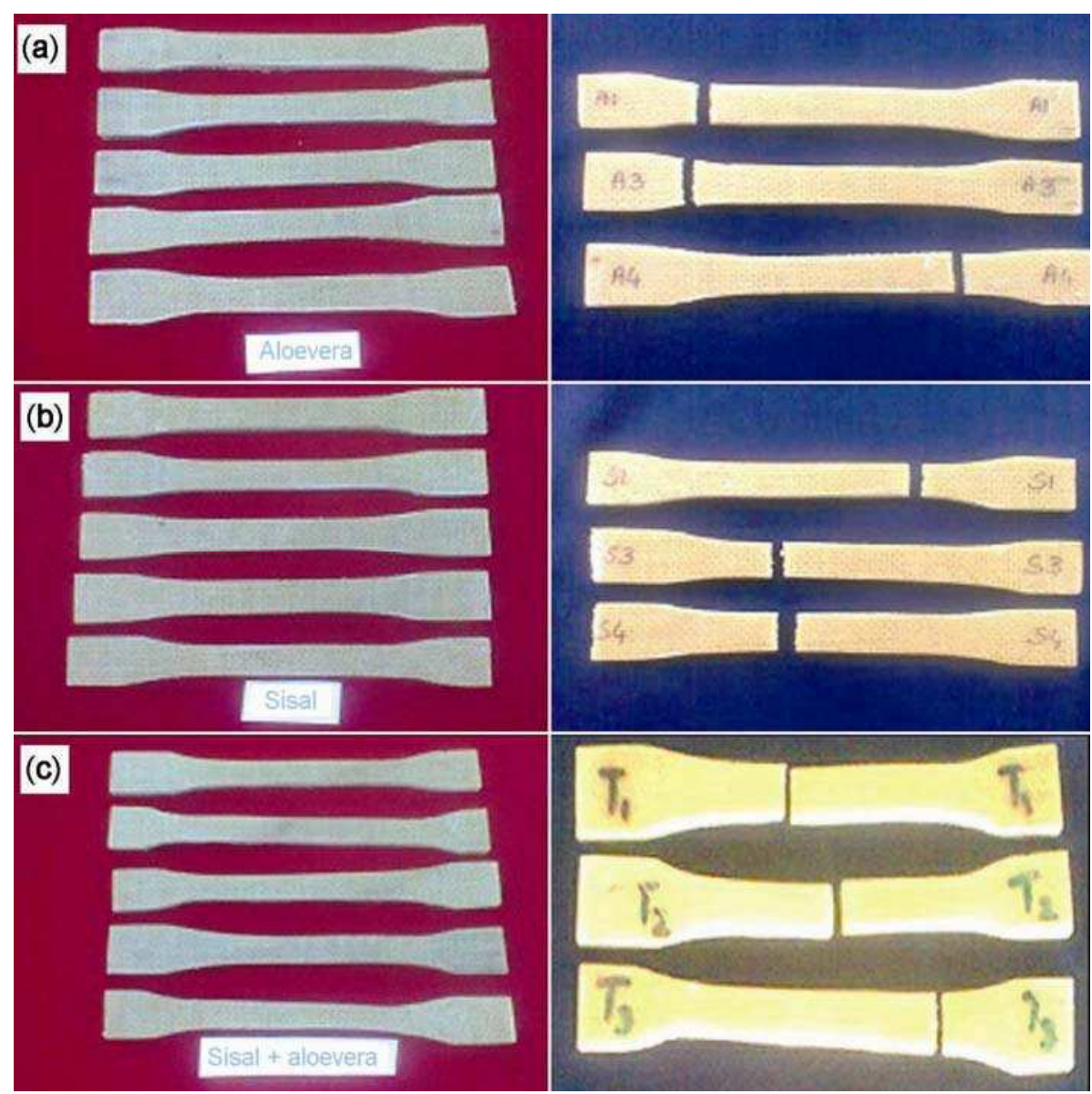

Figure 3. Tensile specimens before testing and after testing of (a) woven aloevera, (b) sisal and (c) sisal and aloevera hybrid composite. 


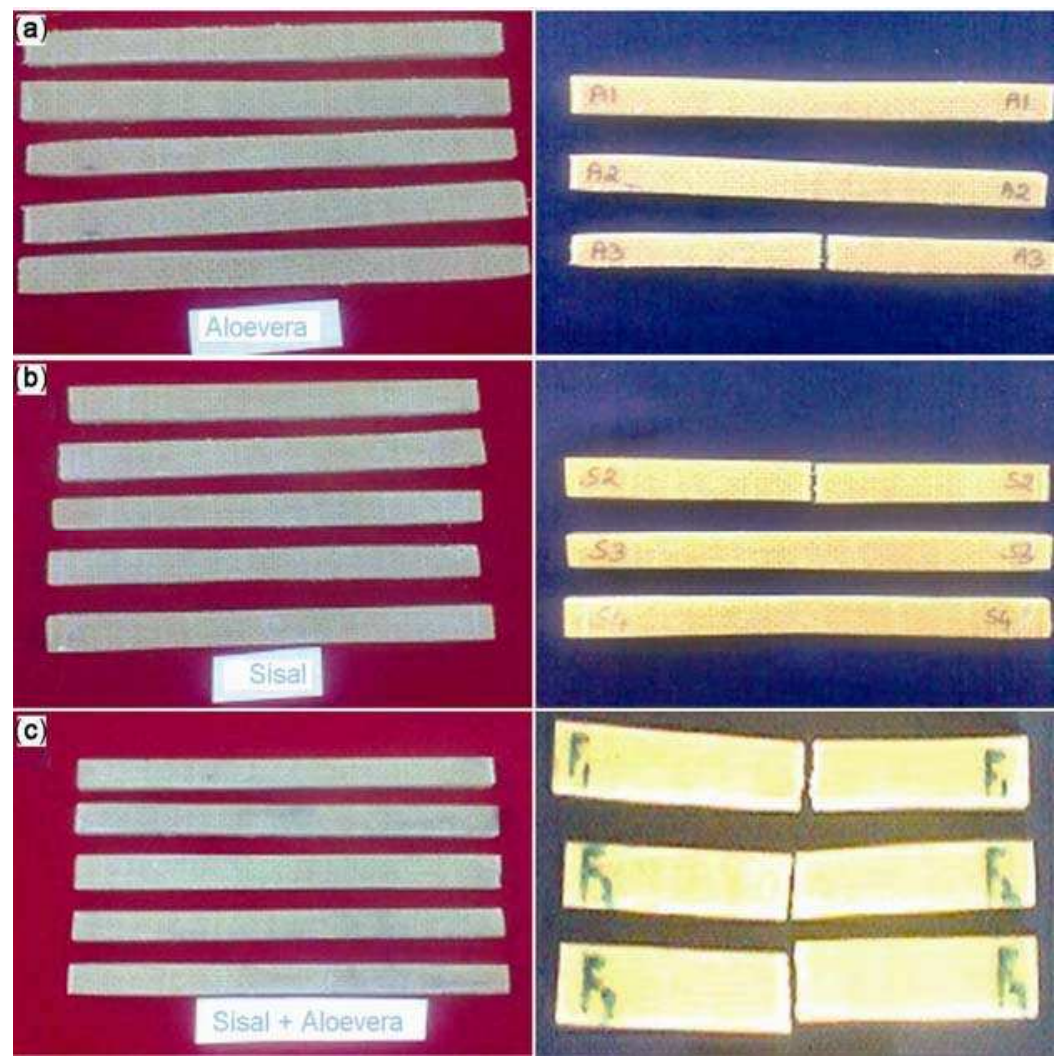

Figure 4. Flexural specimens before testing and after testing of (a) woven aloevera, (b) sisal and (c) sisal and aloevera hybrid composites.

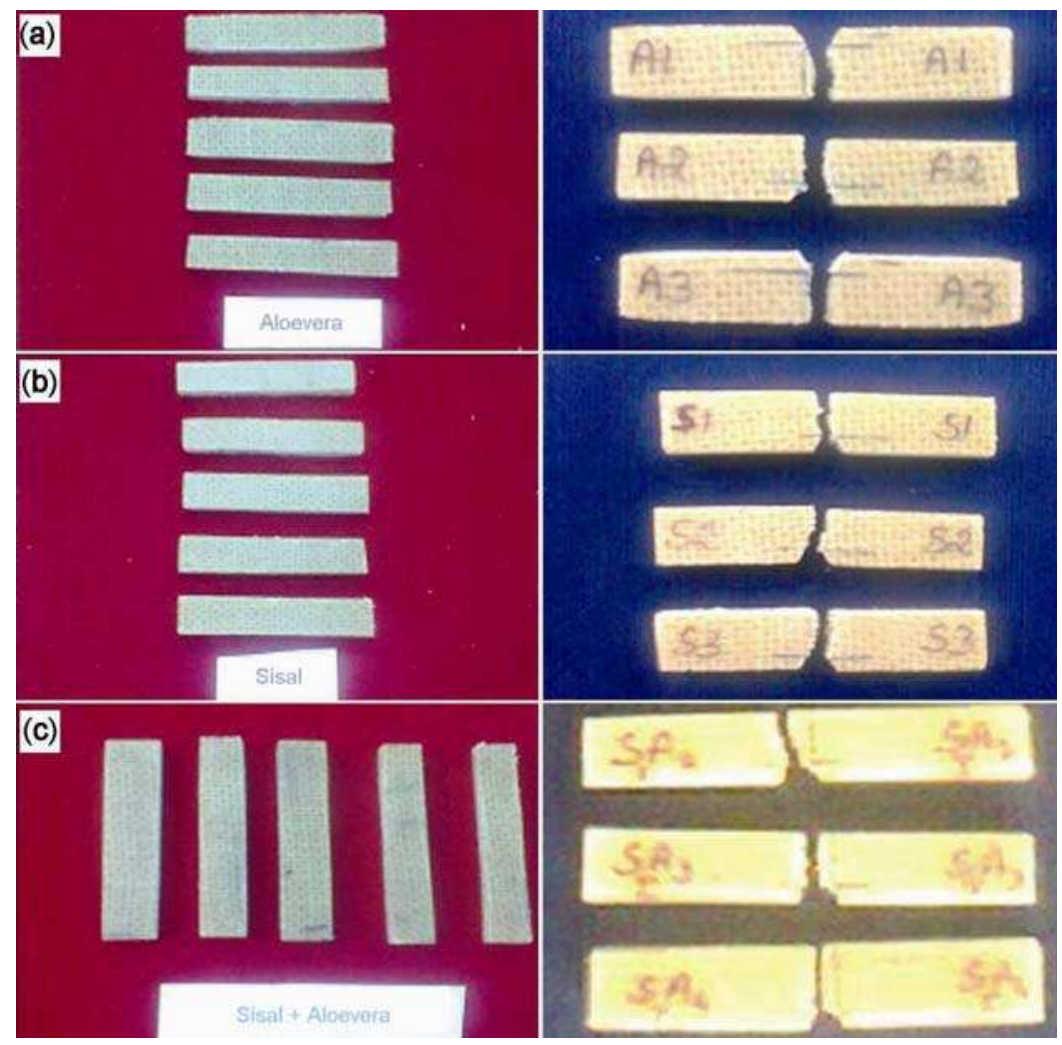

Figure 5. Impact specimens before testing and after testing of (a) woven aloevera, (b) sisal and (c) sisal and aloevera hybrid composites. 


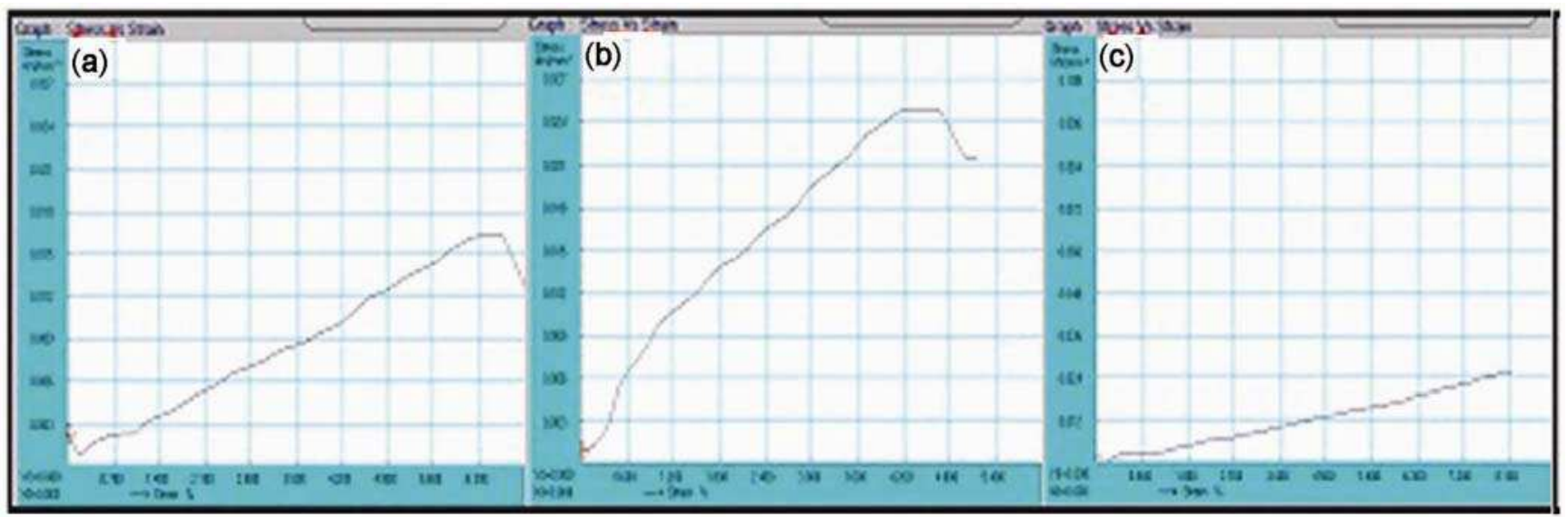

Figure 6. Stress-strain sample graph generated from the machine for tensile test of (a) woven aloevera, (b) sisal and (c) aloevera and sisal hybrid composite specimens.

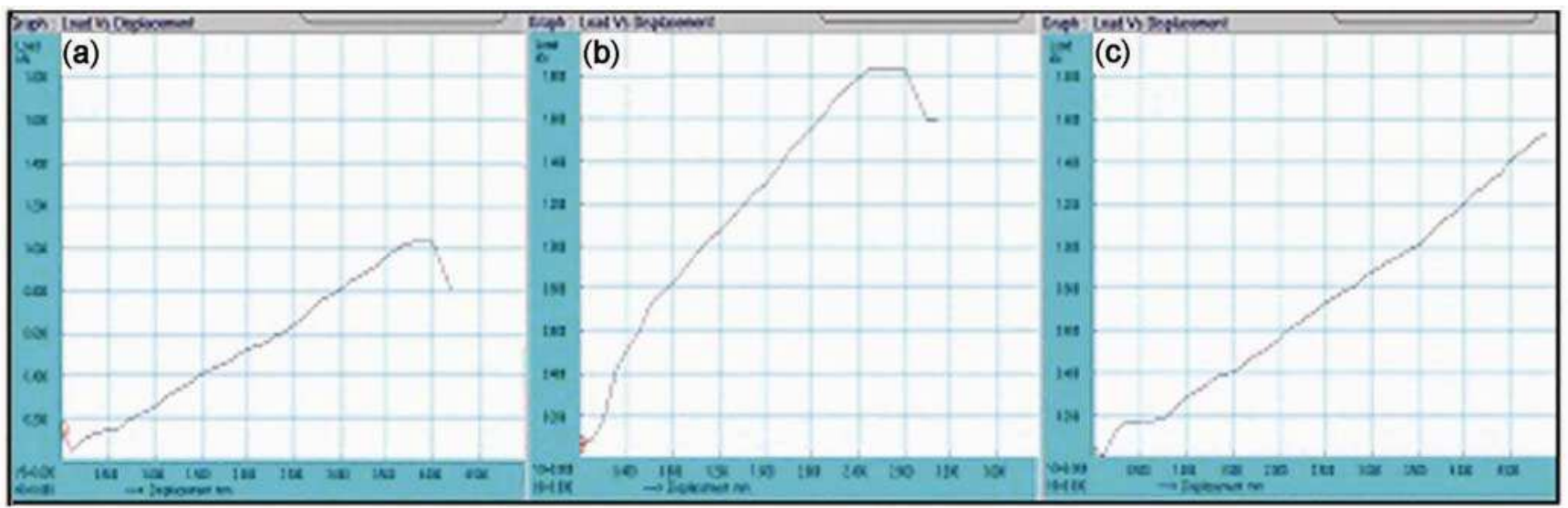

Figure 7. Load-displacement sample graph generated from the machine for tensile test of (a) woven aloevera, (b) sisal and (c) aloevera and sisal hybrid composite specimens.

\section{Results and discussion}

At present, the natural fibres have been used as reinforcement in polymer composites for varieties of applications in automotive components, structures and consumer goods. The main focus of this study is used to find out the mechanical properties like tensile, flexural and impact strength for woven natural fibre aloevera, sisal and its hybrid epoxy composite. The analysis of the surface of the tested samples is carried out by using scanning electron microscope. The tested results for the composite samples are presented in table 1 .

\subsection{Mechanical properties}

The ultimate tensile strength of the aloevera, sisal and its hybrid composite samples are carried out using tensile test. The tensile load observed for the different composite samples tested is presented in figure 10 . The results indicated that the average ultimate tensile strength is maximum for the sisal fibre-reinforced composite and is $1.73 \mathrm{kN}$. The increase of tensile strength is due to the specific properties of sisal fibre when compared to the aloevera fibre. The strength of the sisal fibre is high when compared with aloevera. The strength of the joints may be increased by using the proper proportion of the matrix and the reinforcement. Provided the woven fibre composite have additional features such as interlace spacing or gap, interlace point and unit cell. It has balanced properties by the interlock of fibre arrangement that increases the strength. The tensile strength may be increased if the fibre has undergone various chemical treatments such as mercerization, silane treatment, benzoylation, etc., before made into composites. Hence chemical treatments have improved the surface properties of natural fibres and enhance the adhesive bonding ability of the fibres with the matrix. ${ }^{11}$ Hence by appropriate fibre proportions, hybridization of fibres into the matrix will substantially improve the tensile property. By combining aloevera with 


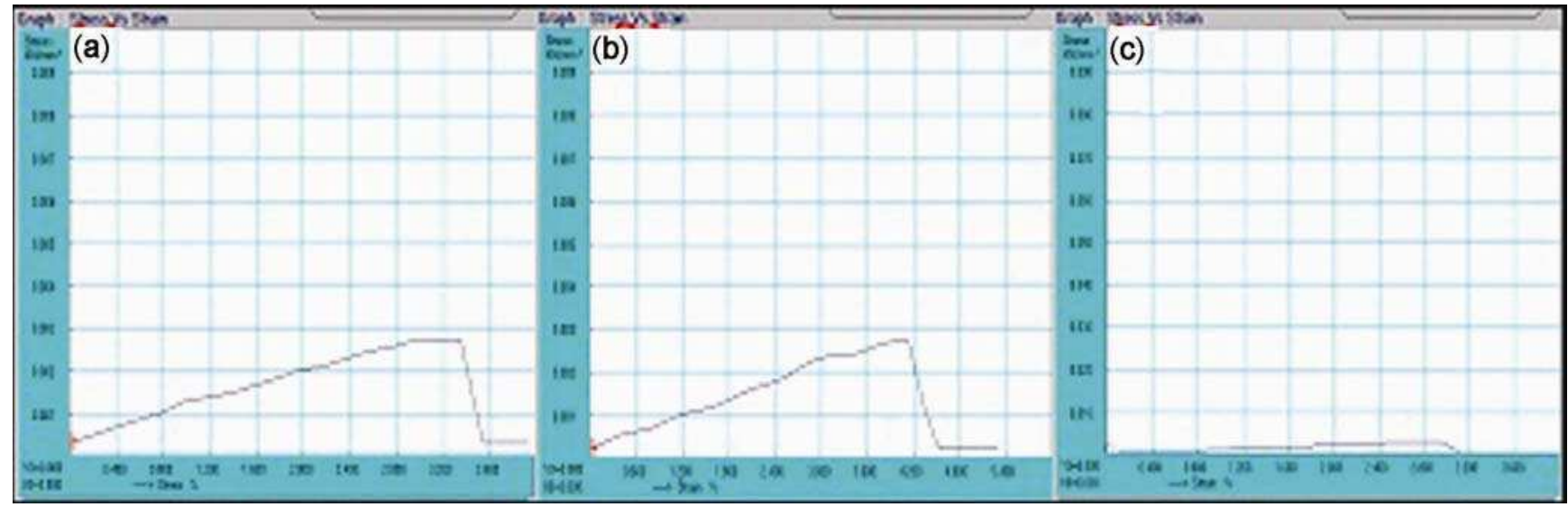

Figure 8. Sress-strain sample graph generated from the machine for flexural test of (a) woven aloevera, (b) sisal and (c) aloevera and sisal hybrid composite specimens.

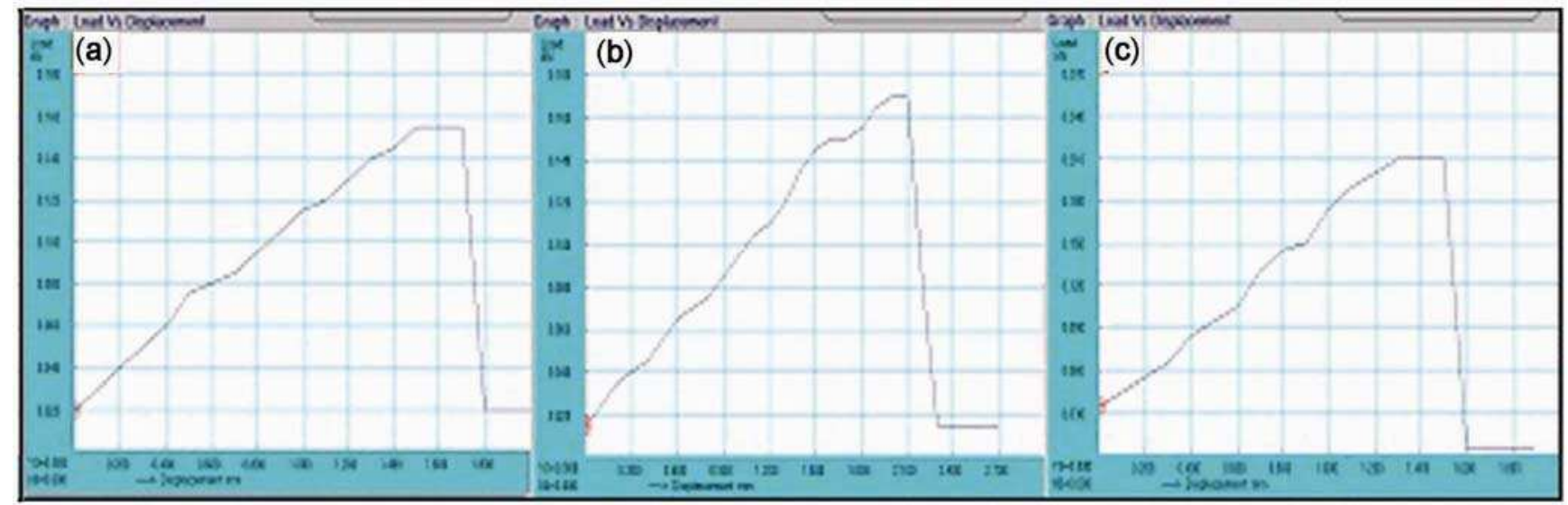

Figure 9. Load-displacement sample graph generated from the machine for flexural test of (a) woven aloevera, (b) sisal and (c) aloevera and sisal hybrid composite specimens.

Table 1. Mechanical properties of tested composites.

\begin{tabular}{|c|c|c|c|c|c|c|c|}
\hline \multirow[b]{2}{*}{ Specimen } & \multicolumn{3}{|c|}{ Tensile properties } & \multicolumn{3}{|c|}{ Flexural properties } & \multirow[b]{2}{*}{$\begin{array}{c}\text { Impact properties/ } \\
\text { strength }(\mathrm{J})\end{array}$} \\
\hline & $\begin{array}{l}\text { Tensile } \\
\text { load }(\mathrm{kN})\end{array}$ & $\begin{array}{c}\text { Tensile } \\
\text { strength } \\
\left(\mathrm{kN} \mathrm{mm}^{-2}\right)\end{array}$ & $\begin{array}{l}\text { Displacement } \\
(\mathrm{mm})\end{array}$ & $\begin{array}{l}\text { Flexural } \\
\text { load }(\mathrm{kN})\end{array}$ & $\begin{array}{c}\text { Flexural } \\
\text { strength } \\
\left(\mathrm{kN} \mathrm{mm}^{-2}\right)\end{array}$ & $\begin{array}{l}\text { Displacement } \\
(\mathrm{mm})\end{array}$ & \\
\hline Aloevera & 1.22 & 0.019 & 3.8 & 0.16 & 0.003 & 2.1 & 0.3 \\
\hline Sisal & 1.73 & 0.025 & 3.6 & 0.18 & 0.003 & 1.9 & 0.4 \\
\hline Aloevera and sisal & 1.53 & 0.027 & 3.9 & 0.17 & 0.003 & 2.2 & 0.6 \\
\hline
\end{tabular}

sisal, the strength observed is comparatively more, which in turn can be used as a material where moderate strength is required.

It is observed that the flexural load-carrying capacity for the sisal composite is $0.185 \mathrm{kN}$, whereas the flexural strength for aloevera is only $0.165 \mathrm{kN}$. The hybrid composite exhibits a strength of $0.173 \mathrm{kN}$, which is more than the aloevera fibre-reinforced composites. The comparative ultimate flexural strength observed for aloevera, sisal and its hybrid composite samples are presented in figure 11. Flexural strength is a measure of stiffness. Observation on specimens indicated that, the proper binding between the fibre and matrix may increase the stiffness of the composite to little extend. By proper treatment of fibres, also the flexural strength of composite can be enhanced. It is important to note that the natural fibres can be replaced in applications where synthetic fibres are used especially in automotive and related industries. The 
change of polymer matrix and its concentration also influences the flexural properties, due to the change in effect of adhesion between the fibre and matrix.

The impact strength of the aloevera, sisal and its hybrid composites are tested by Izod impact tester. Here it is observed that the combination of sisal and aloevera hybrid sample shows better impact energy than the other samples. The maximum impact energy observed is $0.6 \mathrm{~J}$. The result of impact energy obtained for the different samples are plotted in figure 12. Impact strength depends upon the fibre resistivity during fracture. Increase of gsm in woven fibre mat may increases the pull out force and further increase in impact strength. Investigations on specimens show that hybridization of fibres increases the impact strength. Aloevera and sisal hybrid epoxy

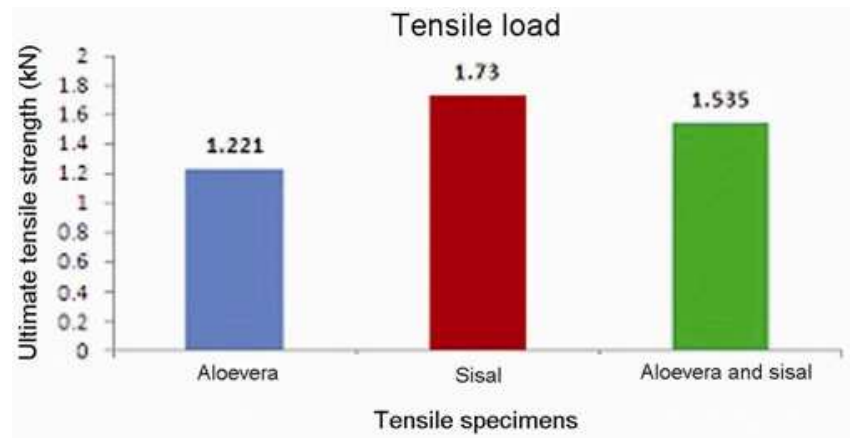

Figure 10. Tensile energy comparison of composite samples.

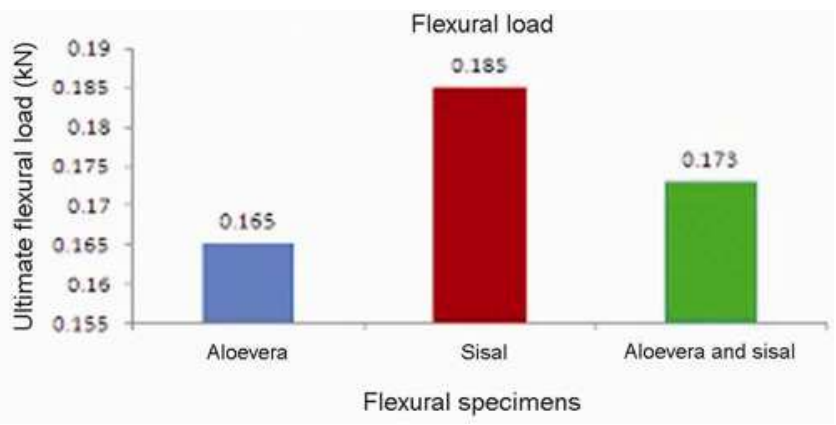

Figure 11. Flexural load energy comparison of composite.

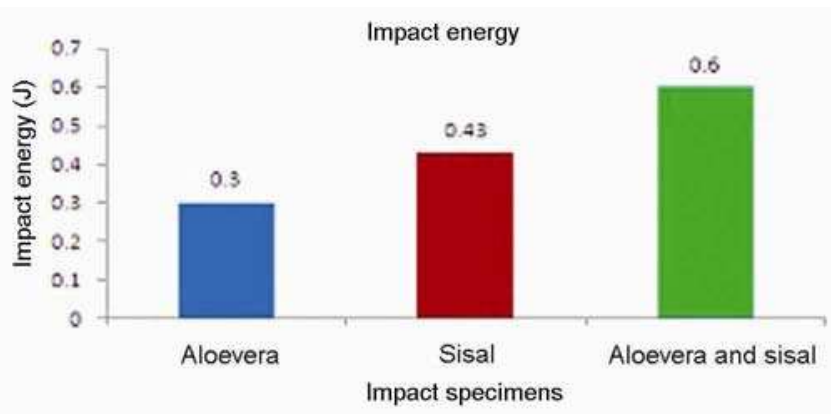

Figure 12. Impact energy comparison of composite samples. composite shows higher impact energy. This is due to the multiple natural fibre arrangement of woven form have the ability to absorb high energy during impact.

From the results, it has been noted that, among the tensile, flexural and impact testing, sisal composite shows better tensile and flexural strength and its hybrid composite shows good impact resistance. The comparative results of load with respect to displacement for tensile test of the composite samples are presented in figure 13a. The results indicated that the hybrid composite sample gives higher displacement of $4.9 \mathrm{~mm}$ for an average load of $1.525 \mathrm{kN}$. Simultaneously for flexural loaddisplacement the results are presented in figure $13 \mathrm{~b}$. In this case it is observed that for the sisal composite a displacement of $2 \mathrm{~mm}$ is obtained for the average load of $0.173 \mathrm{kN}$.

The tensile stress with respect to the strain for the composite samples is presented by graph in figure $14 \mathrm{a}$. The results indicated that the hybrid composite samples give better tensile stress of $0.026 \mathrm{kN} \mathrm{mm}^{-2}$. Similarly flexural stress to strain graph for the samples is presented in figure $14 \mathrm{~b}$. The results indicated that uniformity in flexural stress is maintained as $0.003 \mathrm{kN} \mathrm{mm}^{-2}$ for all the composite samples. From the observations it is found that the natural fibres used in this investigation have comparatively good properties in comparison with natural fibres.

From the investigations of mechanical testing, for the natural woven aloevera, sisal and its hybrid epoxy composite, it has been observed that stability in tensile,
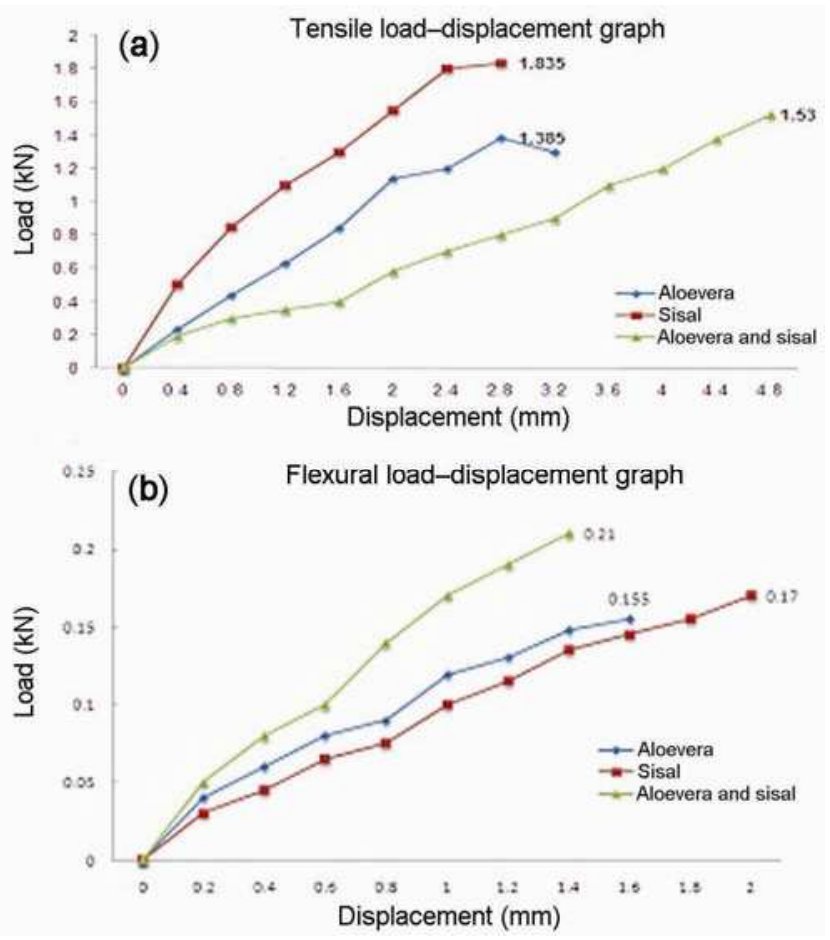

Figure 13. (a) Tensile and (b) flexural load-displacement of different composite samples. 
flexural and impact strength has been found out in all the samples which have been tested. Although superior strength has not been obtained when compared with synthetic fibres. The main aim of this study is to replace synthetic fibres with natural fibres. Hybridization of fibres shows a positive effect on impact properties. Hence it has been asserted that multiple hybridization of natural fibre can improve all the mechanical properties if proper selection and chemical treatments of fibre should be carried out, so that replacement of synthetic fibres can be viable.

\subsection{Scanning electron microscopy}

The SEM images were collected from Carl Zeiss SUPRA 55 FESEM having resolution of $0.8 \mathrm{~nm}$ and the magnification factor ranges from $100 \times$ to $1000 \mathrm{k} \times$. Figure 15 shows the SEM images of prepared samples from the tested specimens of the aloevera, sisal and its hybrid composites which underwent tensile test of magnification factor $100 \times$. The figures representing the fracture takes place in the matrix and fibre materials. As well as it shows the matrix fracture, crack, fibre pull outs and voids in many spots due to the applied tensile load in the composite specimens. The SEM micrograph of tensile fractured

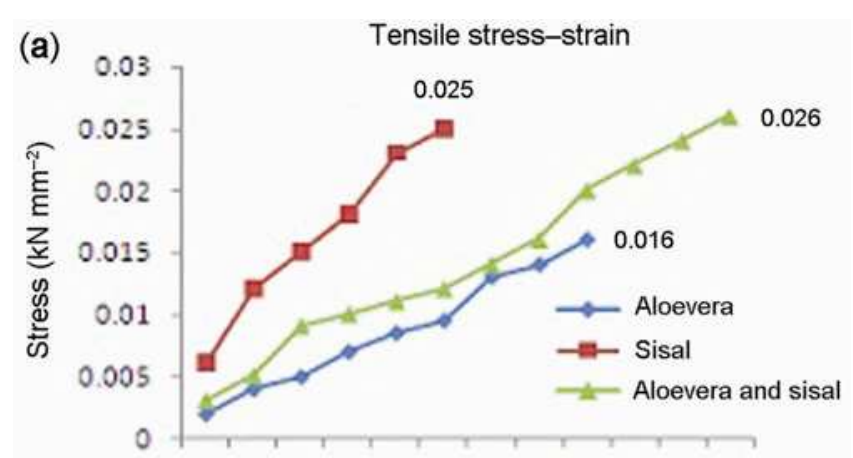

0.71 .42 .12 .83 .54 .24 .95 .66 .377 .78 .1

Strain (\%)

(b)

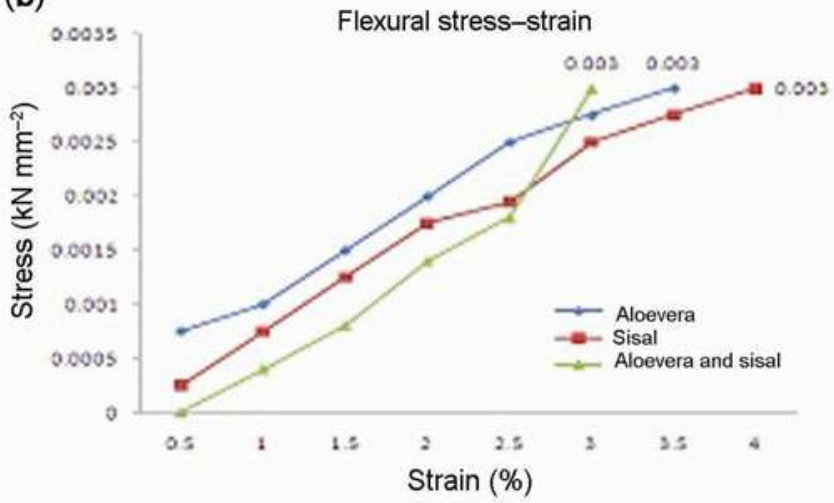

Figure 14. (a) Tensile and (b) flexural stress-strain of different composite samples. specimen shows poor adhesion between the fibre and resin in both fractured and prepared specimens. Hence formation of cavities, voids and less interfacial strength is noted, so stress transfer mechanism will be low. This affects mechanical properties. Hence the samples fail in fracture well in advance. So enough care must be taken in fabricating the composite by appropriate manufacturing method.

Figure 16 shows the SEM images of aloevera, sisal and its hybrid composites which underwent flexural test of magnification factor $100 \times$. In the figure, notification of the
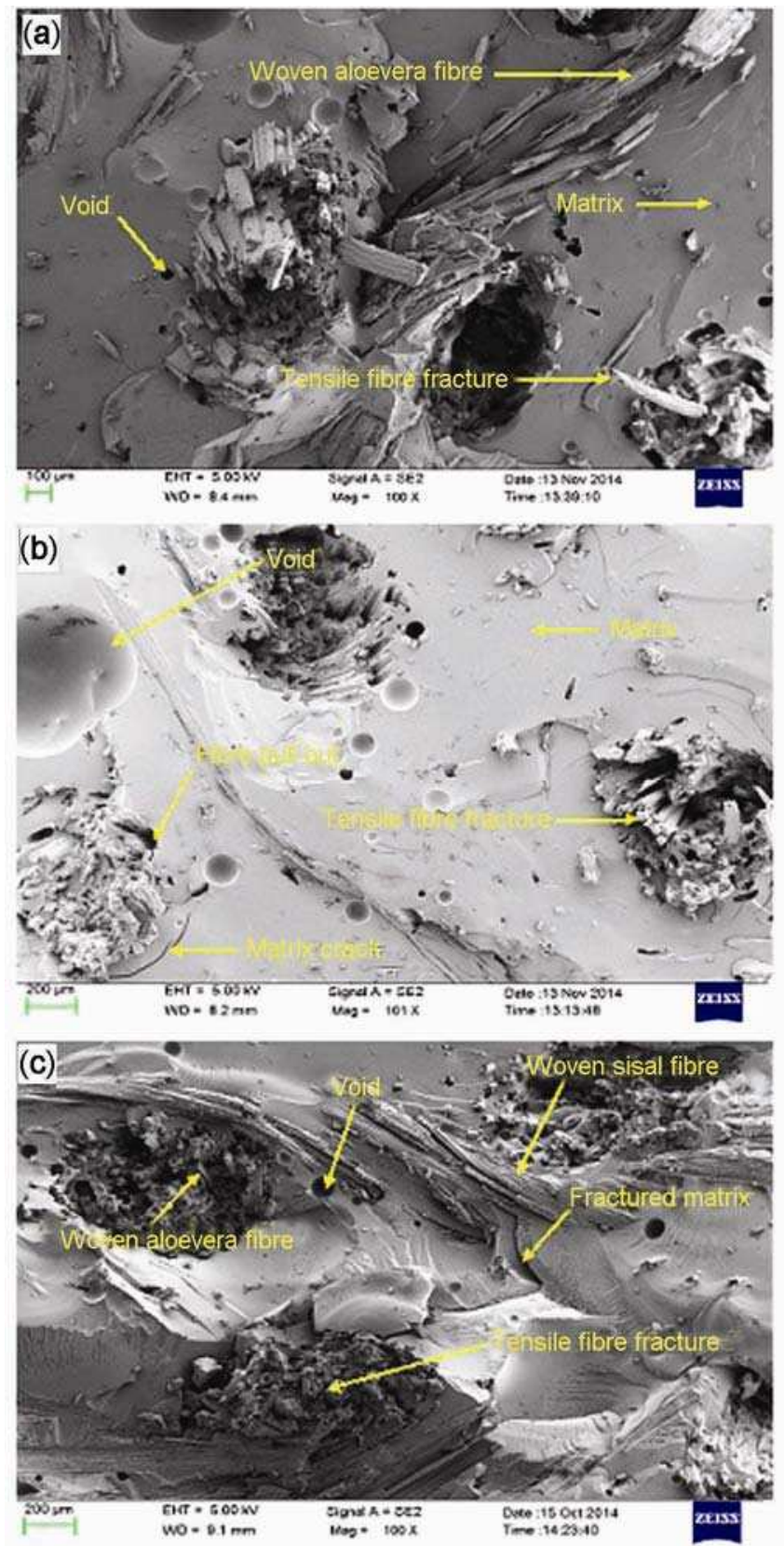

Figure 15. SEM images of (a) woven aloevera, (b) sisal and (c) its hybrid tensile specimens. 
woven fibre fracture, debonding, voids, fibre pullout and matrix fracture and crack are observed. Formation of microholes may be due to improper coverage of resin over the fibres during the hand layup process. Matrix crack observed in flexural specimens is due to improper mixing of resin with hardener. The SEM micrograph of flexural fractured specimen shows denser distribution of matrix in fibre. From the figures, it is observed that the aloevera-reinforced composites have low bonding when compared to the other specimen tested. The void formation and other discontinuity are observed almost in all specimen, but the formation is high in aloevera fibrereinforced specimen.

Figure 17 shows the SEM images of aloevera, sisal and its hybrid composites which underwent impact test of magnification factor $100 \times$. In the figure, dislocation of matrix, fibre-matrix fracture, debonding, voids, fibre pullout and crack are observed similar to the other testing. The fibre pull outs observed in impact specimens through micrographs is due to weak bond between the matrix and fibre. Formation of these factors which have been discussed in
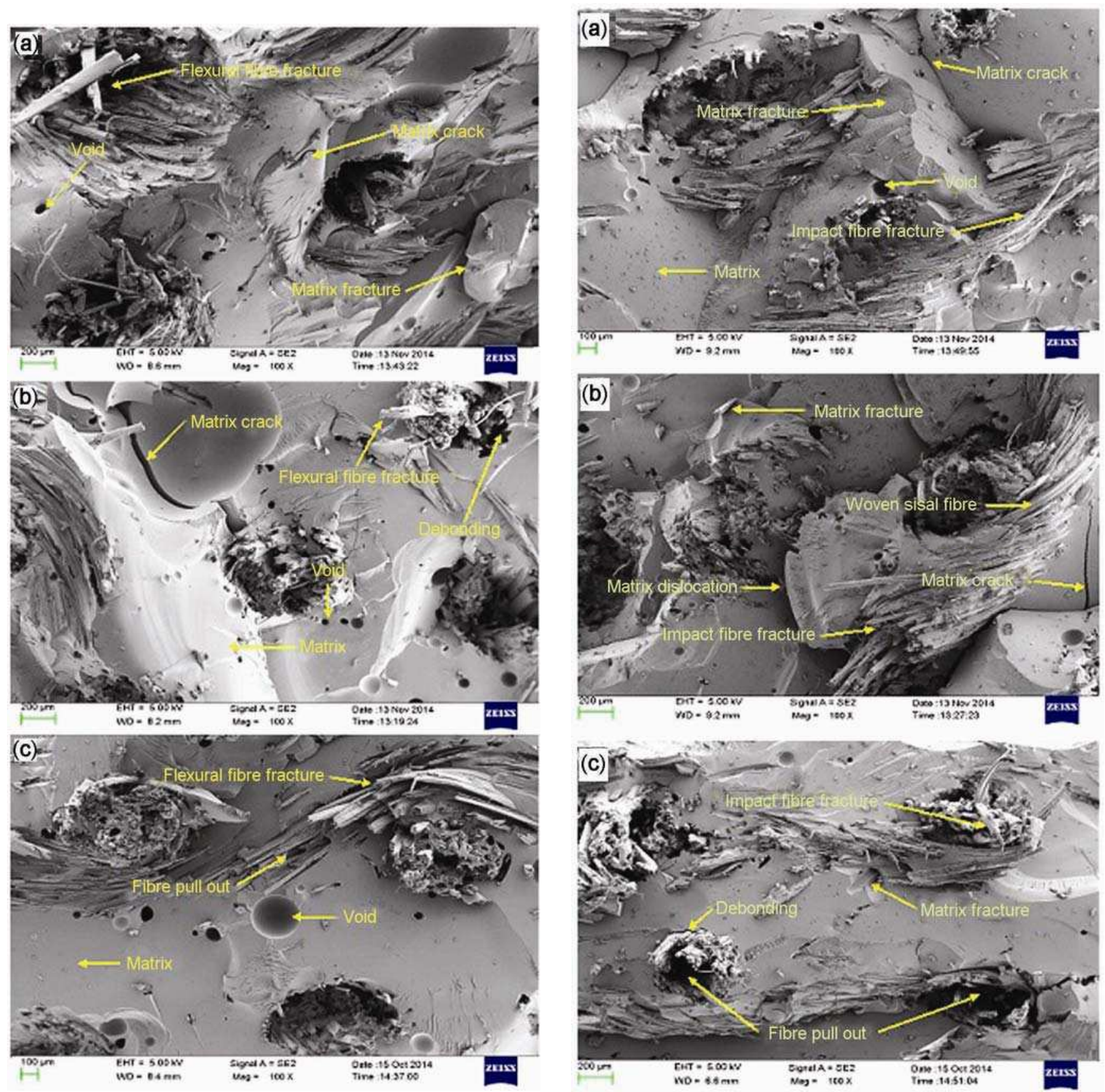

Figure 16. SEM images of (a) woven aloevera, (b) sisal and (c) its hybrid flexural specimens.

Figure 17. SEM images of (a) woven aloevera, (b) sisal and (c) its hybrid impact specimens. 
all the three testing's carried out is responsible for reduction in tensile, flexural and impact strength of the composites. The clear evidence of various defects investigated through SEM micrographs for all the tested specimens will be enhanced by proper chemical treatment to fibres and proper care in fabricating the composite.

\section{Conclusion}

In this study woven aloevera, sisal and its hybrid epoxy composites, tensile, flexural and impact strength were determined using universal testing machine and impact tester. Based on the results the following conclusions are drawn:

1. A new natural fibre aloevera in woven form is experimented in this study.

2. The hybrid composite sample gives higher displacement of $4.9 \mathrm{~mm}$ for an average load of $1.525 \mathrm{kN}$ and gives better tensile stress of $0.026 \mathrm{kN} \mathrm{mm}^{-2}$ during its tensile test.

3. During flexural test the sisal composite had a displacement of $2 \mathrm{~mm}$ for the average load of $0.173 \mathrm{kN}$, and uniformity in flexural stress is maintained as $0.003 \mathrm{kN} \mathrm{mm}^{-2}$ for all the composite samples.

4. The results indicated that woven aloevera and sisal epoxy hybrid composite possess good tensile, flexural and impact strength.

5. From the investigation hybridization of fibres shows good impact strength.

6. Enhancement of mechanical properties may be attained by using the treated fibres and correct method of fabrication.

7. The natural fibre slowly replaces the synthetic fibres from its environmental impact, marching towards to make a revolution in engineering materials.

\section{References}

1. Joshi S V, Drzal L T, Mohanty A K and Arora S 2004 Composites: Part A 35371

2. Palani Kumar K and Shadrach Jeya Sekaran A 2014 J. Reinf. Plast. Compos. 331879

3. Ho M-P, Wang H, Lee J-H, Ho C-K, Lau K-T, Leng J and Hui D 2012 Composites: Part B 433549

4. Malkapuram R, Kumar V and Negi Y S 2009 J. Reinf. Plast. Compos. 281169

5. Singha A S and Thakur V K 2008 Bull. Mater. Sci. 31791
6. Velumani S, Navaneethakrishnan P, Jayabal S and Robinson Smart D S 2013 Bull. Mater. Sci. 36575

7. Rong M Z, Zhang M Q, Liu Y, Yang G C and Zeng H M 2001 Compos. Sci. Technol. 611437

8. Li Y, Mai Y-W and Ye L 2000 Compos. Sci. Technol. 60 2037

9. Sydenstricker T H D, Mochnaz S and Amico S C 2003 Polym. Test. 22375

10. Goud G and Rao R N 2011 Bull. Mater. Sci. 341575

11. Zhu J, Zhu H, Njuguna J and Abhyankar H 2013 Materials 65171

12. Venkateshwaran N, Elayaperumal A and Sathiya G K 2012 Composites: Part B $\mathbf{4 3} 793$

13. de Andrade Silva F, Mobasher B and Toledo Filho R D 2010 Mater. Sci. Eng. A 5275507

14. Popa M I, Pernevan S, Sirghie C, Spiridon I, Chambre D, Copolovici D M and Popa N 2013 (Hindawi Publishing Corporation) J. Chem. Article ID 343068, p 8; http://dx. doi.org/10.1155/2013/343068

15. Ramesh M, Palanikumar K and Hemachandra Reddy K 2013 Proc. Eng. 51745

16. Rathika S, Palanikumar K and Raghavan P S 2014 Asian J. Chem. 2616049

17. Shadrach Jeya Sekaran A, Palani Kumar K, Pitchandi K and Karunamoorthy L 2015 Appl. Mech. Mater. 766-767 110

18. Nunna S, Ravi Chandra P, Shrivastava S and Jalan A K 2012 J. Reinf. Plast. Compos. 31759

19. Sahari J and Sapuan S M 2011 Rev. Adv. Mater. Sci. 30 166

20. Martins M A, Pessoa J D C, Gonçalves P S, Souza F I and Mattoso L H C 2008 J. Mater. Sci. 43 6531, doi: $10.1007 / \mathrm{s} 10853-008-2842-4$

21. Islam M N, Dungani R, Abdul Khalil H P S, Siti Alwan M, Wan Nadirah W O and Mohammad Fizree H 2013 Springer Plus 2 592, http://www.springerplus.com/content/2/1/592

22. Kabir H, Gafur M A, Ahmed F, Begum F and Qadir M R 2014 Univers. J. Mater. Sci. 2119

23. Srinivasan V S, Rajendra Boopathy S, Sangeetha D and Vijaya Ramnath B 2014 Mater. Des. 60620

24. Sharma N K and Kumar V 2013 J. Reinf. Plast. Compos. 32525

25. Venkateshwaran N, Elaya Perumal A, Alavudeen A and Thiruchitrambalam M 2011 Mater. Des. 324017

26. ASTM D638-03 Standard test method for testing tensile properties of plastics

27. ASTM D790-07 Standard tests method for testing flexural properties of unreinforced and reinforced plastics and electrical insulating material

28. ASTM D256-06a Standard test method for determining izod pendulum impact resistance of plastics 